\title{
TGF- $\beta 1$ induces the dissolution of tight junctions in human renal proximal tubular cells: Role of the RhoA/ROCK signaling pathway
}

\author{
KE ZHANG, HAO ZHANG, HUI XIANG, JISHI LIU, YAN LIU, XIANMING ZHANG, \\ JIANWEN WANG and YOUZHOU TANG
}

Department of Nephrology, The Third Xiangya Hospital, Central South University, Changsha, Hunan 410013, P.R. China

Received March 9, 2013; Accepted May 20, 2013

DOI: $10.3892 /$ ijmm.2013.1396

\begin{abstract}
The RhoA/ROCK signaling pathway plays a significant role in transforming growth factor (TGF)- $\beta 1$-mediated epithelial-mesenchymal transition (EMT). It remains unclear, however, whether the RhoA/ROCK signaling pathway mediates TGF- $\beta 1$-induced EMT by promoting the dissolution of tight junctions (TJs) in renal proximal tubular epithelial cells. In this study, we aimed to investigate the association between TGF- $\beta 1$-mediated Rho/ROCK signaling and TJs in a cell line derived from human renal proximal tubular cells (HK-2 cells). HK-2 cells were treated with $5 \mathrm{ng} / \mathrm{ml}$ TGF- $\beta 1$ for 0,12 , 24 and $48 \mathrm{~h}$. Zona occludens protein 1 (also known as tight junction protein $1 ; \mathrm{ZO}-1$ ) and occludin mRNA and protein levels were determined by real-time PCR and western blot analysis, respectively. The HK-2 cells were then divided into three groups: a control group (serum-free culture medium for $24 \mathrm{~h}$ ); a TGF- $\beta 1$ group (treated with $5 \mathrm{ng} / \mathrm{ml} \mathrm{TGF}-\beta 1$ for $24 \mathrm{~h}$ ); and a TGF- $\beta 1+\mathrm{Y}-27632$ (a specific ROCK inhibitor) group (pre-treated with $10 \mu \mathrm{M} \mathrm{Y}-27632$ for $2 \mathrm{~h}$ and subsequently treated with $5 \mathrm{ng} / \mathrm{ml}$ TGF- $\beta 1$ for $24 \mathrm{~h}$ ). The levels of ZO-1 and occludin were detected by real-time PCR, western blot analysis and immunofluorescence. As shown by our results, the mRNA and protein levels of ZO-1 and occludin were decreased in the HK- 2 cells following treatment with TGF- $\beta 1$ in a time-dependent manner; in addition, $\mathrm{ZO}-1$ and occludin levels in the TGF- $\beta 1+$ Y-27632 group were significantly increased compared with those of the TGF- $\beta 1$ group $(\mathrm{P}<0.05)$, with no significant changes compared with the control group. Our results indicate that the Rho/ROCK signaling pathway
\end{abstract}

Correspondence to: Professor Hao Zhang, Department of Nephrology, The Third Xiangya Hospital, Central South University, No. 138 Tongzipo Road, Changsha, Hunan 410013, P.R. China

E-mail: zhanghaoliaoqing@163.com

Key words: renal fibrosis, transforming growth factor- $\beta 1$, Rho/ ROCK signaling pathway, epithelial-mesenchymal transition, tight junctions mediated by TGF- $\beta 1$ plays a role in the dissolution of TJs during EMT.

\section{Introduction}

Tubular epithelial-mesenchymal transition (EMT) is the critical initiating agent in tubulointerstitial fibrosis (1-3). The dissolution of tight junctions (TJs) is an early event in EMT $(4,5)$, which is preceded by the downregulation of adhesion molecules, including claudins, occludin, zona occludens protein 1 (also known as tight junction protein $1 ; \mathrm{ZO}-1$ ) and desmoplakin. Transforming growth factor (TGF)- $\beta 1$ plays a vital role in EMT regulation. The Smad, RhoA/ROCK and p38/MAPK signaling pathways play important roles in TGF- $\beta$-induced EMT in different epithelial cells (6-10). Tian et al (11) provided evidence of the function of TGF- $\beta 1$-induced RhoA activation in renal proximal tubular epithelial cells. Our previous study suggested that the RhoA/ROCK signaling pathway mediates TGF- $\beta 1$-induced EMT in rat peritoneal mesothelial cells (RPMCs) (12), and the changes characteristic of EMT were partially reversed by Y-27632, a ROCK inhibitor. In another previous study, we suggested that the Smad signaling pathway mediates TGF- $\beta 1$-induced EMT in human peritoneal mesothelial cells (HPMCs) (13). It remains unclear, however, whether the RhoA/ROCK signaling pathway mediates TGF- $\beta 1$-induced EMT by promoting the dissolution of TJs in renal proximal tubular epithelial cells. In this study, we selected the HK-2 cell line to investigate this process, as these cells are commonly used as an in vitro model of normal human proximal tubular cells (14). We aimed to determine the role of the RhoA/ROCK signaling pathway in regulating the TGF- $\beta 1$-induced dissolution of TJs in HK-2 cells. In addition, we explored the potential of this process as a therapeutic target for the prevention of early-stage EMT.

\section{Materials and methods}

In vitro cell culture. The human renal proximal tubular epithelial cell line, HK-2, which was purchased from ATCC (Manassas, VA, USA) and maintained in a defined medium [1:1 mixture of DMEM and Ham's F-12 (Gibco/Invitrogen, Carlsbad, CA, USA) containing $10 \%$ fetal bovine serum 
(FBS), penicillin $(100 \mathrm{U} / \mathrm{ml})$, streptomycin $(100 \mu \mathrm{g} / \mathrm{ml})$, insulin $(0.5 \mu \mathrm{g} / \mathrm{ml})$, transferrin $(5 \mu \mathrm{g} / \mathrm{ml})$ and hydrocortisone $(1 \mu \mathrm{g} / \mathrm{ml})]$ at $37^{\circ} \mathrm{C}$ in a $5 \% \mathrm{CO}_{2}$ environment. After the cells achieved $80 \%$ cell confluency, the medium was changed to FBS-free DMEM/F12. First, $5 \mathrm{ng} / \mathrm{ml}$ TGF- $\beta 1$, which is a concentration commonly used in EMT in in vitro studies (15) (Pepro Tech Inc., Rocky Hill, NJ, USA), was added at different time points $(0,12,24$ and $48 \mathrm{~h})$. Second, the HK-2 cells were divided into three groups: a control group (FBS-free DMEM/ F1 2 for $24 \mathrm{~h}$ ); a TGF- $\beta 1$ group $(5 \mathrm{ng} / \mathrm{ml} \mathrm{TGF-} \beta 1$ treatment for $24 \mathrm{~h}$ ); and a TGF- $\beta 1+$ Y-27632 group [pre-treated with $10 \mu \mathrm{M}$ Y-27632 (Calbiochem, San Diego, CA, USA) and then treated with TGF- $\beta 1$ for $24 \mathrm{~h}]$. mRNA and protein expression were determined by real-time PCR and western blot analysis, respectively.

Gene expression. Total RNA from the HK-2 cells was isolated using TRIzol reagent. Real-time PCR was performed with an Applied Biosystems 7300 Real-Time PCR System (Applied Biosystems, Bedford, MA, USA) using a SYBR-Green PCR reagent kit (Invitrogen). The change in mRNA levels was determined using the $2^{-\Delta \Delta \mathrm{CT}}$ method, where $\Delta \mathrm{CT}$ is the value from the threshold cycle (CT) of the treated sample subtracted from the $\mathrm{CT}$ value of the untreated or zero time point control sample. The relative amount of mRNA in the sample was normalized to $\beta$-actin mRNA. The PCR primers were as follows: occludin (106 bp) sense, 5'TCCAGAGTCTTCCTATAAATCCAC3' and antisense, 5'ACCACCGCTGCTGTAACG3'; ZO-1 (134 bp) sense, 5'TGGTGTCCTACCTAATTCAACTCA3' and antisense, 5'CGCCAGCTACAAATATTCCAACA3'; $\beta$-actin (231 bp) sense, 5'ACTCTTCCAGCCTTCCTTCC 3 ' and antisense, 5'GAGGAGCAATGATCTTGATCTTC3'. The primers were synthesized by Invitrogen Shanghai (Shanghai, China).

Protein expression. Protein expression was evaluated by western blot analysis according to a previously described method (16). Total protein from the HK-2 cells was isolated using RIPA lysis buffer (Beijing Dingguo Changsheng Biotechnology Co. Ltd., Beijing, China) containing a cocktail of protease inhibitors. Primary antibodies included anti-occludin (1:400) and anti-ZO-1 (1:500) (Santa Cruz Biotechnology, Inc. Santa Cruz, CA, USA). The absorbance signal was analyzed using Image Station 4000 MM (Kodak, Rochester, NY, USA).

Immunofluorescence. Immunohistochemical staining was performed on the HK-2 cells using anti-ZO-1 and antioccludin antibodies (Santa Cruz Biotechnology, Inc.). HK-2 cells were grown on poly-L-lysine-coated glass coverslips (BD Biosciences, San Jose, CA, USA) to 40-50\% confluence, serum-deprived overnight (DMEM $+1 \%$ FBS), and then treated with TGF- $\beta 1$ in the presence or absence of a 2-h pretreatment with Y-27632. Following fixation with acetone, the cells were permeabilized in 1\% Triton X-100 (Sigma-Aldrich, St. Louis, MO, USA) and blocked with 5\% BSA. The cells were incubated with primary antibodies (to ZO-1 and occludin) overnight at $4^{\circ} \mathrm{C}$. The slides were then washed and incubated with the appropriate FITC-conjugated secondary antibody. The cells were then incubated with Hoechst 33342 (Invitrogen) for nuclear staining and mounted with propyl gallate under glass coverslips. Finally, the cells were visualized by immunofluorescence with a laser scanning Nikon microscope at x20 magnification. Each experiment was repeated three times.

Statistical analysis. The Data presented in this study are expressed as the means \pm SE. One-way ANOVA was used to assess the measurement data and the least significant difference t-test was used to assess statistical differences between pairs of groups. A P-value $<0.05$ was considered to indicate a statistically significant difference.

\section{Results}

TGF- $\beta 1$ downregulates occludin and $\mathrm{ZO}-1$ expression in $\mathrm{HK}-2$ cells. The HK- 2 cells were exposed to TGF- $\beta 1$ as indicated above, and the mRNA and protein levels of occludin were assessed by real-time PCR and western blot analysis, respectively. Treatment with TGF- $\beta 1$ decreased occludin mRNA (Fig. 1A) and protein (Fig. 1B) levels as compared with those of the control group in a time-dependent manner. The mRNA and protein levels were significantly decreased after $24(\mathrm{P}<0.05)$ and $48 \mathrm{~h}$ of treatment $(\mathrm{P}<0.05)$, suggesting that TGF- $\beta 1$ induced the dissolution of TJs in the HK-2 cells.

The HK- 2 cells were exposed to TGF- $\beta 1$ as indicated above, and the mRNA and protein levels of ZO-1 were assessed by real-time PCR and western blot analysis, respectively. Treatment with TGF- $\beta 1$ decreased the mRNA (Fig. $2 \mathrm{~A}$ ) and protein (Fig. 2B) levels of ZO-1 as compared with those of the control group in a time-dependent manner. The mRNA and protein levels were significantly decreased after $24(\mathrm{P}<0.05)$ and $48 \mathrm{~h}$ of treatment $(\mathrm{P}<0.05)$, providing further evidence that TGF- $\beta 1$ induced the dissolution of TJs in HK-2 cells.

Y-27632 attenuates the downregulation of occludin and ZO-1 induced by TGF- $\beta 1$ in $\mathrm{HK}-2$ cells. The HK-2 cells were pretreated with $10 \mu \mathrm{M} \mathrm{Y}-27632$ for $2 \mathrm{~h}$ and then treated with $5 \mathrm{ng} / \mathrm{ml}$ TGF- $\beta 1$ for $48 \mathrm{~h}$. The expression of occludin was assessed by real-time PCR, immunofluorescence and western blot analysis (Fig. 3). Treatment with TGF- $\beta 1$ decreased the expression of occludin (Fig. 3B; D and E column 2) compared with that of the control group (Fig. 3A; D and E column 1) $(\mathrm{P}<0.05)$. This decrease in occudin expression was attenuated in the cells treated with TGF- $\beta 1+$ Y-27632 (Fig. 3C; D and E column 3), and was not significantly different from that in the control group $(\mathrm{P}>0.05)$. Thus, the TGF- $\beta 1$-induced downregulation in occludin expression in the HK-2 cells was attenuated by the ROCK inhibitor, Y-27632.

The HK-2 cells were pre-treated with $10 \mu \mathrm{M} \mathrm{Y}-27632$ for $2 \mathrm{~h}$ and then treated with $5 \mathrm{ng} / \mathrm{ml}$ TGF- $\beta 1$ for $48 \mathrm{~h}$. The expression of ZO-1 was assessed by real-time PCR, immunofluorescence and western blot analysis (Fig. 4). Treatment with TGF- $\beta 1$ decreased the expression of ZO- 1 (Fig. 4B; D and E column 2) compared with that of the control group (Fig. 4A; $\mathrm{D}$ and E column 1) $(\mathrm{P}<0.05)$. This decrease in $\mathrm{ZO}-1$ expression was attenuated in the cells treated with TGF- $\beta 1+$ Y-27632 (Fig. 4C; D and E column 3), and was not significantly different from that in the control group $(\mathrm{P}>0.05)$. These results suggested that the TGF- $\beta 1$-induced downregulation in ZO-1 expresision in the HK-2 cells was attenuated by the ROCK inhibitor, Y-27632. 


\section{A}
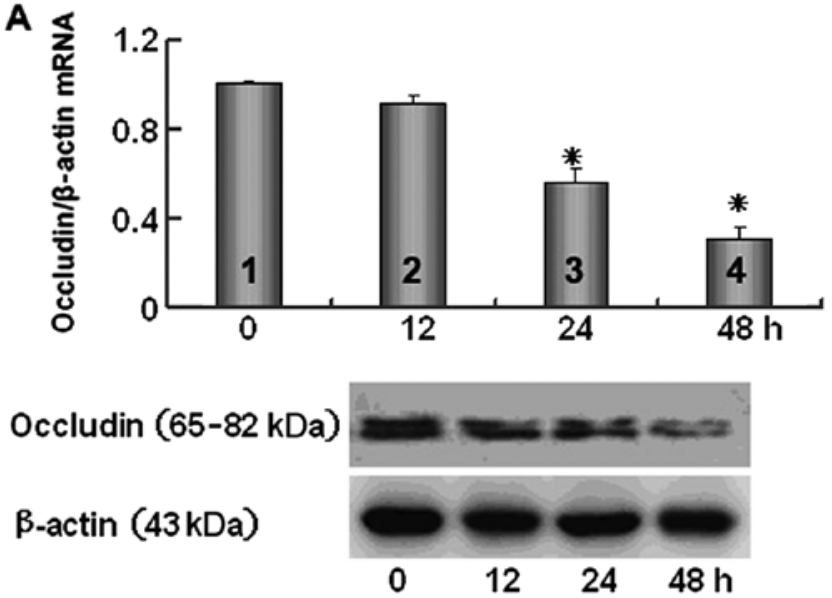

$\mathbf{B}$

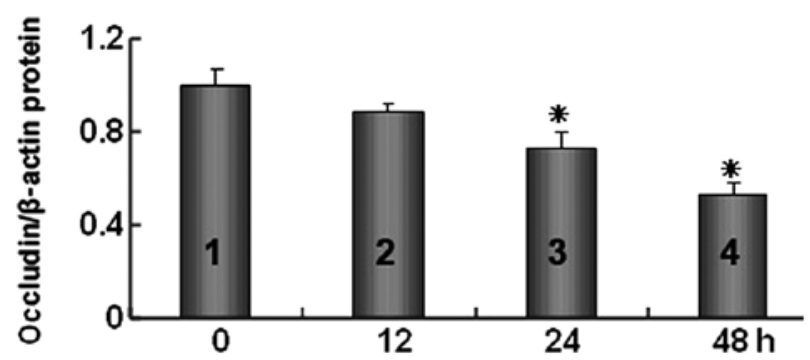

Figure 1. TGF- $\beta 1$ downregulates the expression level of occludin in HK-2 cells. (A and B) Treatment with TGF- $\beta 1$ decreased the expression of occludin in a time-dependent manner in the HK-2 cells at the mRNA and protein level, respectively. (A) The $2^{-\Delta \Delta \mathrm{CT}}$ value of occludin relative to that of $\beta$-actin in HK-2 cells following exposure to TGF- $\beta 1(5 \mathrm{ng} / \mathrm{ml}, 0-48 \mathrm{~h})$. The expression of occludin decreased in a time-dependent manner in the HK-2 cells treated with TGF- $\beta 1$ (columns $2-4$ ). The $2^{-\Delta \Delta C T}$ values for occludin mRNA levels in HK-2 cells treated with TGF- $\beta 1$ for 12,24 and $48 \mathrm{~h}$ were $0.917 \pm 0.028$ $(\mathrm{P}>0.05), 0.560 \pm 0.055(\mathrm{P}<0.05)$ and $0.306 \pm 0.047(\mathrm{P}<0.05)$, respectively. (B) Densitometry value for occludin relative to that of $\beta$-actin detected by western blot analysis in HK-2 cells following exposure to TGF- $\beta 1(5 \mathrm{ng} / \mathrm{ml}$, $0-48 \mathrm{~h}$ ). The ratios of occludin protein relative to those of $\beta$-actin in HK-2 cells treated with TGF- $\beta 1$ for 12,24 and $48 \mathrm{~h}$ were $0.883 \pm 0.038(\mathrm{P}>0.05)$, $0.730 \pm 0.072(\mathrm{P}<0.05)$, and $0.528 \pm 0.046(\mathrm{P}<0.05)$, respectively. ${ }^{*} \mathrm{P}<0.05$ vs. control group.

\section{Discussion}

Tubular interstitial fibrosis is an important component of chronic kidney disease (CKD). The key event of tissue fibrosis involves EMT induced by TGF- $\beta 1$, which involves the differentiation of epithelial cells into fibroblasts. TJs are the most apical component of the intercellular junctional complex and play a vital role in maintaining epithelial polarity (17). Occludin and ZO-1 are key components of TJs. The dissociation of TJs is an early, significant event in EMT (18). According our results, the decreased expression of ZO-1 and occludin was observed in the HK- 2 cells treated with TGF- $\beta 1$ as early as $12 \mathrm{~h}$, and this decrease continued at 24 and $48 \mathrm{~h}$ after treatment in a timedependent manner, suggesting that the dissolution of TJs is a critical event during EMT.

Previous studies have suggested that the RhoA/ROCK signaling pathway is involved in actin reorganization and cell migration. It has been confirmed that RhoA is activated by TGF- $\beta 1$ and is part of an important signaling pathway in TGF- $\beta 1$-induced EMT $(11,12)$. ROCK is a characteristic, downstream protein in the Rho signaling pathway and an important
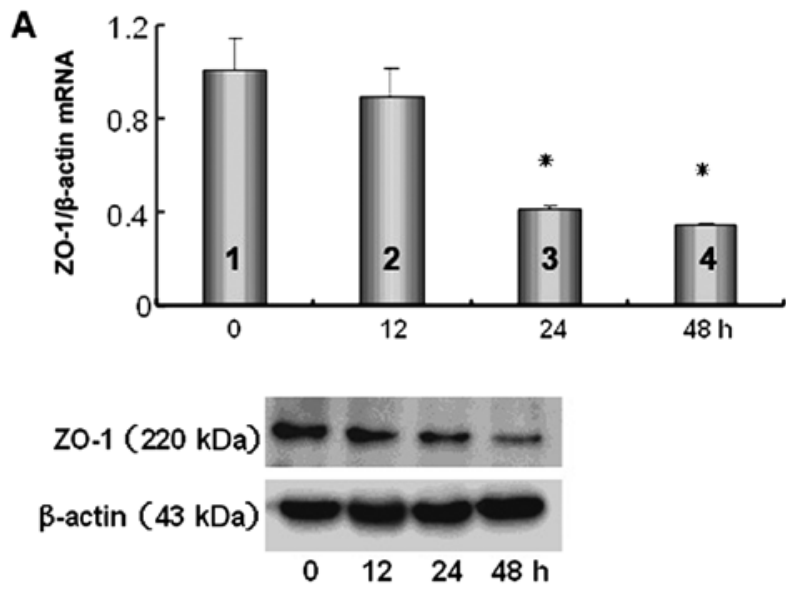

B

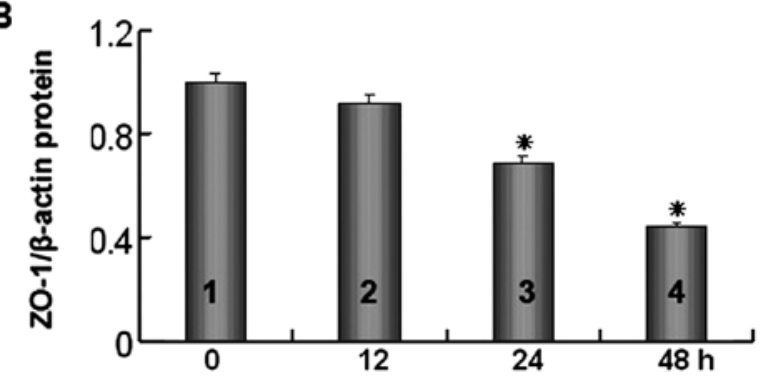

Figure 2. TGF- $\beta 1$ downregulates the level of ZO-1 in HK-2 cells (A and B) TGF- $\beta 1$ treatment decreased the expression of ZO-1 in a timedependent manner in HK-2 cells at the mRNA and protein level, respectively. (A) The $2^{-\triangle \Delta C T}$ value of ZO- 1 relative to that of $\beta$-actin in HK- 2 cells following exposure to TGF- $\beta 1(5 \mathrm{ng} / \mathrm{ml}, 0-48 \mathrm{~h})$. The expression of ZO-1 decreased in a time-dependent manner in HK-2 cells treated with TGF- $\beta 1$ (columns 2-4). The $2^{-\Delta \Delta \mathrm{CT}}$ values of the ZO-1 mRNA expression level in HK-2 cells treated with TGF- $\beta 1$ for 12,24 and $48 \mathrm{~h}$ were $0.895 \pm 0.117$ ( $\mathrm{P}>0.05), 0.406 \pm 0.021$ $(\mathrm{P}<0.05)$, and $0.345 \pm 0.008(\mathrm{P}<0.05)$, respectively. (B) Densitometry value of $\mathrm{ZO}-1$ relative to that of $\beta$-actin detected by western blot analysis in HK-2 cells following exposure to TGF- $\beta 1(5 \mathrm{ng} / \mathrm{ml}, 0-48 \mathrm{~h})$. The ratios of ZO-1 protein relative to those of $\beta$-actin in HK-2 cells treated with TGF- $\beta 1$ for 12,24 and $48 \mathrm{~h}$ were $0.916 \pm 0.036(\mathrm{P}>0.05), 0.691 \pm 0.027(\mathrm{P}<0.05)$ and $0.442 \pm 0.012$ $(\mathrm{P}<0.05)$, respectively. ${ }^{*} \mathrm{P}<0.05$ vs. control group.

kinase involved in the regulation of cell movement and cytoskeletal organization (19-21). Y-27632, a 4-aminopyridine-type chemical used in studies on cell biology and pharmacology, is generally accepted to be a specific ROCK inhibitor.

Previous studies on the Rho/ROCK pathway have mainly focused on the regulation of the cytoskeleton and the mechanisms by which the Rho/ROCK pathway mediates EMT (22-25). Our previous study revealed that TGF- $\beta 1$ induced the downregulation of vimentin (a cytoskeletal protein) and the upregulation of $\alpha$-SMA via the RhoA/ROCK signaling pathway in RPMCs (12). Other stueis, however, have shown that the Rho/ROCK signaling pathway may also mediate the downregulation of claudin-4, which is a component of TJs in corneal, gastric epithelial and Madin-Darby canine kidney epithelial cells (26-28), indicating that the Rho/ROCK signaling pathway may play a role in the dissolution of TJs. Nevertheless, it is unclear whether the RhoA/ROCK signaling pathway mediates TGF- $\beta 1$-induced EMT by targeting TJs and inducing their dissolution in HK-2 cells.

In this study, the ROCK inhibitor, Y-27632, attenuated the downregulation in ZO-1 and occludin expression at the 
A

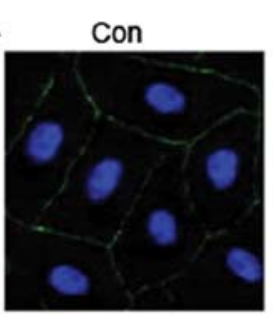

B
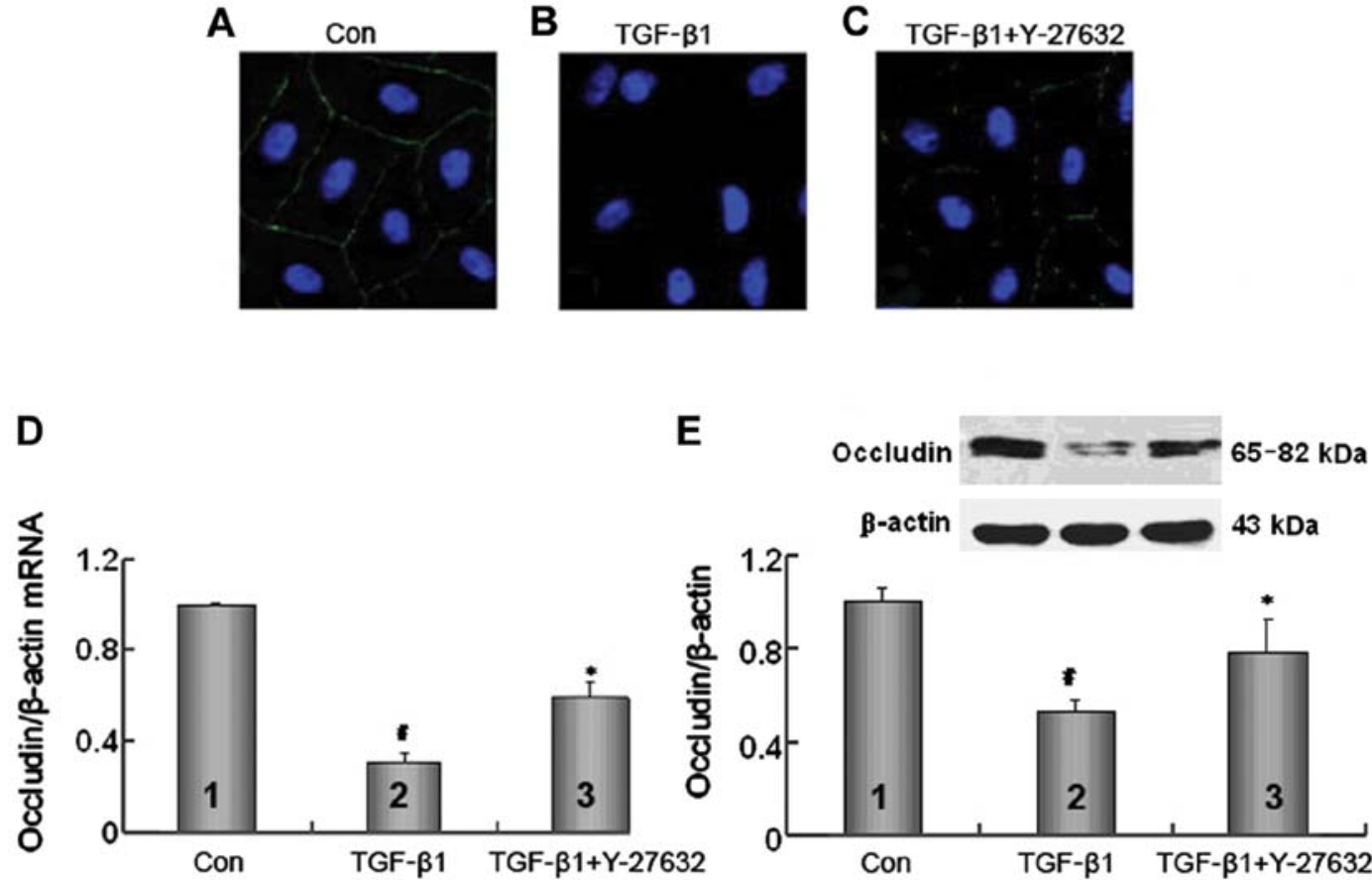

Figure 3. Y-27632 attenuates the downregulation of occludin induced by TGF- $\beta 1$ in HK-2 cells. (A-C) Protein expression of occludin detected by immunofluorescence. (D) mRNA expression of occludin detected by real-time PCR; (E) protein expression of occludin detected by western blot analysis. Treatment with TGF- $\beta 1$ decreased the expression level of occludin (B; D and E, column 2). This decrease was attenuated by blocking the RhoA/ROCK signaling pathway with Y-27632, a ROCK inhibitor (C; D and E, column 3). Y-27632 partially reversed the TGF- $\beta 1$-induced downregulation in the mRNA and protein expression of occludin. ${ }^{\text {P }}<0.05$ vs. control group; ${ }^{*} \mathrm{P}<0.05$ vs. TGF- $\beta 1$-treated group.
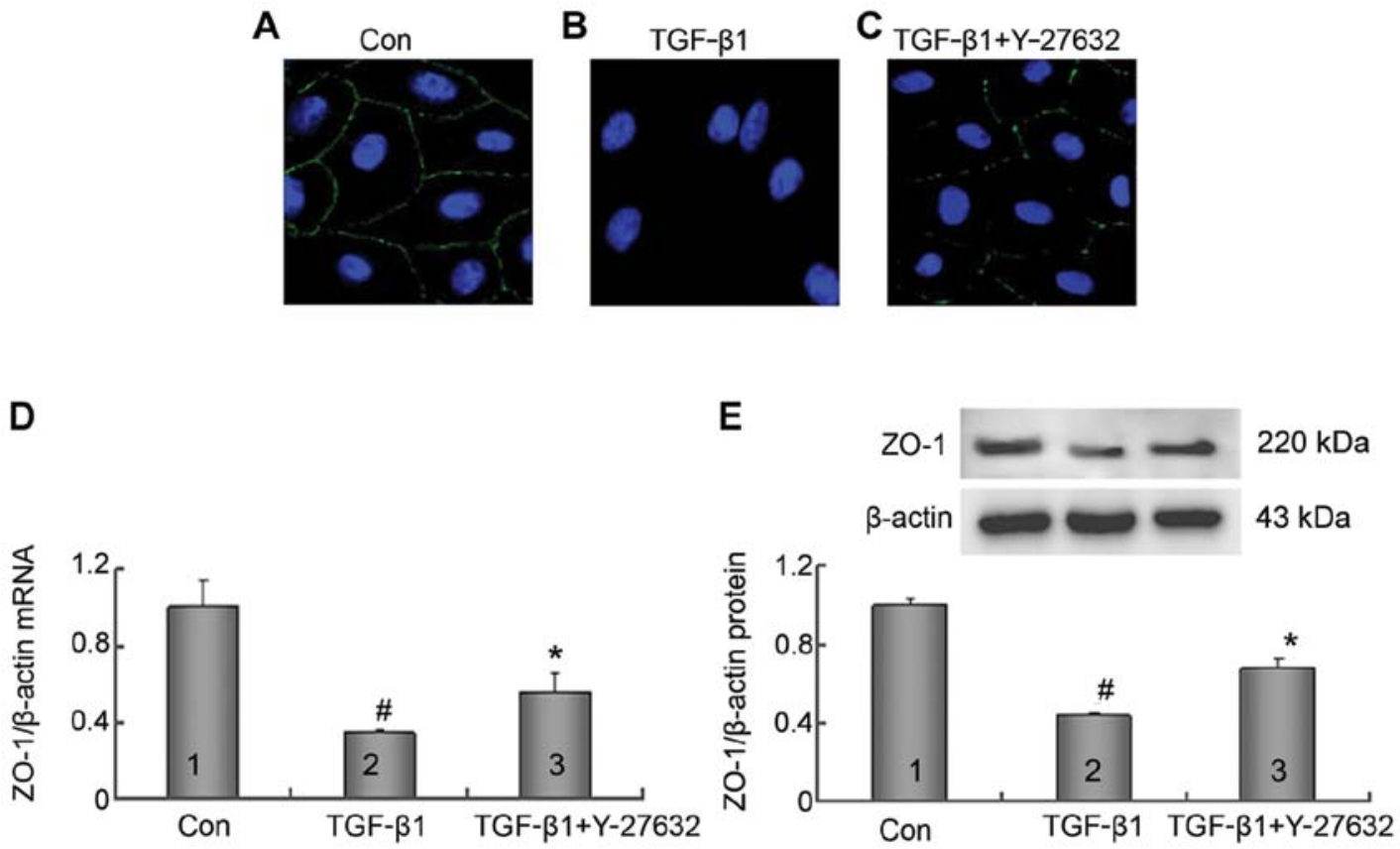

Figure 4. Y-27632 attenuates the downregulation of ZO-1 induced by TGF- $\beta 1$ in HK-2 cells. (A-C) Protein expression of ZO-1 detected by immunofluorescence. (D) mRNA expression of ZO-1 detected by real-time PCR; (E) protein expression of ZO-1 detected by western blot analysis. Treatment with TGF- $\beta 1$ decreased the expression level of ZO-1 (B; D and E, column 2). This decrease was attenuated by blocking the RhoA/ROCK signaling pathway with Y-27632, a ROCK inhibitor (C; D and E, column 3). Y-27632 partially reversed the TGF- $\beta 1$-induced downregulation in the mRNA and protein expression of ZO-1. ${ }^{.} \mathrm{P}<0.05$ vs. control group; ${ }^{*} \mathrm{P}<0.05$ vs. TGF- $\beta 1$ treated group.

gene and protein level, which was induced by TGF- $\beta 1$ by blocking the Rho/ROCK signaling pathway. These results reveal that the Rho/ROCK signaling pathway plays a key role in the dissolution of TJs, an early and reversible event in EMT. However, it was observed that following treatment with TGF- $\beta 1$ and Y-27632, the ZO-1 mRNA levels were only half 
of the control levels, which suggests that RhoA/ROCK is not the only regulator of ZO-1 expression.

In conclusion, in this study, we determined that the dissolution of TJs occurs in HK-2 cells exposed to TGF- $\beta 1$, possiby involving the activation of the Rho/ROCK signaling pathway. Understanding the involvement of the Rho/ROCK signaling pathway in EMT is critical, particularly during the early stages of this process. Since EMT plays a critical role in renal disease, the results from this study may aid in the development of more effective diagnostic markers and therapeutic strategies for patients with CKD.

\section{References}

1. Rastaldi MP: Epithelial-mesenchymal transition and its implications for the development of renal tubulointerstitial fibrosis. J Nephrol 19: 407-412, 2006

2. Li MX and Liu BC: Epithelial to mesenchymal transition in the progression of tubulointerstitial fibrosis. Chinese Med J 120: 1925-1930, 2007.

3. Liu Y: Cellular and molecular mechanisms of renal fibrosis. Nat Rev 7: 684-696, 2011.

4. Blanco D, Vicent S, Elizegi E, Pino I, Fraga MF, Esteller M, Saffiotti U, Lecanda F and Montuenga LM: Altered expression of adhesion molecules and epithelial-mesenchymal transition in silica-induced rat lung carcinogenesis. Lab Invest 84: 999-1012, 2004.

5. Ozdamar B, Bose R, Barrios-Rodiles M, Wang HR, Zhang Y and Wrana JL: Regulation of the polarity protein Par6 by TGFbeta receptors controls epithelial cell plasticity. Science 307: 1603-1609, 2005.

6. Kolosova I, Nethery D and Kern JA: Role of Smad2/3 and p38 MAP kinase in TGF-beta1-induced epithelial-mesenchymal transition of pulmonary epithelial cells. J Cell Physiol 226: $1248-1254,2011$

7. Lampropoulos P, Zizi-Sermpetzoglou A, Rizos S, Kostakis A, Nikiteas $\mathrm{N}$ and Papavassiliou AG: TGF-beta signalling in colon carcinogenesis. Cancer Lett 314: 1-7, 2011.

8. Lv ZM, Wang Q, Wan Q, Lin JG, Hu MS, Liu YX and Wang R: The role of the p38 MAPK signaling pathway in high glucose-induced epithelial-mesenchymal transition of cultured human renal tubular epithelial cells. PloS One 6: e22806, 2011.

9. Matsuzaki K: Smad phosphoisoform signaling specificity: the right place at the right time. Carcinogenesis 32: 1578-1588, 2011.

10. Schneider D and Janshoff A: Inhibition of actin dynamics during epithelial-to-mesenchymal transition. Biochem Biophys Res Commun 419: 221-225, 2012.

11. Tian YC, Fraser D, Attisano L and Phillips AO: TGF-beta1mediated alterations of renal proximal tubular epithelial cell phenotype. Am J Physiol 285: F130-F142, 2003.

12. Zhang H, Liu X, Liu Y, Yi B and Yu X: Epithelial-mesenchymal transition of rat peritoneal mesothelial cells via Rhoa/Rock pathway. In Vitro Cell Dev Biol 47: 165-172, 2010.

13. Zhang H, Liu FY and Liu YH: Effect of TGF-beta1 stimulation on the smad signal transduction pathway of human peritoneal mesothelial cells. Zhong Nan Da Xue Xue Bao Yi Xue Ban 29: 142-147, 2004 (In Chinese).
14. Ryan MJ, Johnson G, Kirk J, Fuerstenberg SM, Zager RA and Torok-Storb B: HK-2: an immortalized proximal tubule epithelial cell line from normal adult human kidney. Kidney Int 45: 48-57, 1994.

15. Black D, Lyman S, Qian T, Lemasters JJ, Rippe RA, Nitta T, Kim JS and Behrns KE: Transforming growth factor beta mediates hepatocyte apoptosis through Smad3 generation of reactive oxygen species. Biochimie 89: 1464-1473, 2007.

16. Sun L, Xiao L, Nie J, Liu FY, Ling GH, Zhu XJ, Tang WB, Chen WC, Xia YC, Zhan M, Ma MM, Peng YM, Liu H, Liu YH and Kanwar YS: p66Shc mediates high-glucose and angiotensin II-induced oxidative stress renal tubular injury via mitochondrial-dependent apoptotic pathway. Am J Physiol 299: F1014-F1025, 2010.

17. Ronaldson PT, Demarco KM, Sanchez-Covarrubias L, Solinsky CM and Davis TP: Transforming growth factor-beta signaling alters substrate permeability and tight junction protein expression at the blood-brain barrier during inflammatory pain. J Cereb Blood Flow Metab 29: 1084-1098, 2009.

18. Inumaru J, Nagano O, Takahashi E, Ishimoto T, Nakamura $S$, Suzuki Y, Niwa S, Umezawa K, Tanihara H and Saya H: Molecular mechanisms regulating dissociation of cell-cell junction of epithelial cells by oxidative stress. Genes Cells 14: 703-716, 2009.

19. Deroanne CF, Hamelryckx D, Ho TT, Lambert CA, Catroux P, Lapiere CM and Nusgens BV: Cdc42 downregulates MMP-1 expression by inhibiting the ERK1/2 pathway. J Cell Sci 118: 1173-1183, 2005.

20. Dovas A, Choi Y, Yoneda A, Multhaupt HA, Kwon SH, Kang D, Oh ES and Couchman JR: Serine 34 phosphorylation of rho guanine dissociation inhibitor (RhoGDIalpha) links signaling from conventional protein kinase C to RhoGTPase in cell adhesion. J Biol Chem 285: 23296-23308, 2010.

21. Leung TH, Ching YP, Yam JW, Wong CM, Yau TO, Jin DY and Ng IO: Deleted in liver cancer 2 (DLC2) suppresses cell transformation by means of inhibition of RhoA activity. Proc Natl Acad Sci USA 102: 15207-15212, 2005.

22. Edlund S, Landstrom M, Heldin $\mathrm{CH}$ and Aspenstrom P: Transforming growth factor-beta-induced mobilization of actin cytoskeleton requires signaling by small GTPases Cdc42 and RhoA. Mol Biol Cell 13: 902-914, 2002.

23. Lee HT and Kay EP: FGF-2 induced reorganization and disruption of actin cytoskeleton through PI 3-kinase, Rho, and Cdc42 in corneal endothelial cells. Mol Vision 9: 624-634, 2003.

24. Patel S, Takagi KI, Suzuki J, Imaizumi A, Kimura T, Mason RM, Kamimura T and Zhang Z: RhoGTPase activation is a key step in renal epithelial mesenchymal transdifferentiation. J Am Soc Nephrol 16: 1977-1984, 2005.

25. Ruiz-Loredo AY, Lopez E and Lopez-Colome AM: Thrombin promotes actin stress fiber formation in RPE through Rho/ROCKmediated MLC phosphorylation. J Cell Physiol 226: 414-423, 2011.

26. Lapointe TK, O'Connor PM, Jones NL, Menard D and Buret AG: Interleukin-1 receptor phosphorylation activates Rho kinase to disrupt human gastric tight junctional claudin-4 during Helicobacter pylori infection. Cell Microbiol 12: 692-703, 2010.

27. Yin J and Yu FS: Rho kinases regulate corneal epithelial wound healing. Am J Physiol 295: C378-C387, 2008.

28. Bruewer M, Hopkins AM, Hobert ME, Nusrat A and Madara JL: RhoA, Rac1, and Cdc42 exert distinct effects on epithelial barrier via selective structural and biochemical modulation of junctional proteins and F-actin. Am J Physiol 287: C327-C335, 2004. 